\title{
EVALUERING VAN DIE BENUTTING VAN GEMEENSKAPSDIENSTE DEUR BEJAARDES IN ’N SEMI-STEDELIKE GEBIED
}

\author{
H Strydom, AA Roux
}

INLEIDING

'n Behoefte het by die bestuur van die Potchefstroom Dienssentrum vir Bejaardes ontstaan om die bestaande gemeenskapsdienste vir bejaardes te evalueer ten einde te kan vasstel waarom bejaardes by ' $n$ dienssentrum aansluit en van sekere dienste gebruik maak; waarom ander nie wil aansluit nie en watter dienste hulle as belangrik sou beskou indien hulle wel daarvan gebruik sou maak. Die probleem sal eerstens omlyn word, waarna die doelstelling en doelwitte vir die ondersoek bespreek sal word. Die teoretiese begronding vir die ondersoek en die navorsingsmetodologie sal bespreek word, waarna die bevindinge van die empiriese ondersoek weergegee sal word. Gevolgtrekkings en aanbevelings rond die artikel af.

\section{PROBLEEMSTELLING}

Ten spyte van die hoë voorkoms van lewensbedreigende siektes soos kanker en hartsiektes leef mense steeds langer (Benokraitis, 1996:507; Strydom, 2001:98-99). In beide ontwikkelde en ontwikkelende lande word ' $n$ toename in die bejaardebevolking waargeneem. Selfs die oudste bejaardes kan nog oor relatief goeie gesondheid beskik en in 'n hoë mate selfstandig funksioneer. Dit is egter ook waar dat, namate mense ouer word, 'n toename in swak gesondheid, hetsy fisies en/of psigies, voorkom en ook 'n afname in doeltreffende vermoë ten opsigte van daaglikse funksionering (Wicclair, 1993:201).

Die moderne samelewing is toenemend ingestel op 'n individualistiese model, wat daarop neerkom dat versorging deur die kinders en informele versorgingstrategieë nie werklik meer 'n plek in die moderne samelewing het nie. Ten spyte van oproepe deur die wetgewers dat elke gemeenskap na sy eie lede moet omsien (Ministry for Welfare and Population Development, 1997:117-119) en dat gemeenskapsdienste vir bejaardes gemeenskapgebaseerd moet wees (Eckley, 1996:50), is die praktyk van so 'n aard dat mense toenemend na binne gekeer leef en minder tyd vir ander maak.

'n Verskeidenheid faktore beïnvloed die aanvraag na en voorsiening van gemeenskapsdienste vir bejaardes, byvoorbeeld 'n toename in lewensverwagting sonder noodwendig 'n toename in goeie gesondheid (Tourigny, Durand, Bonin, Hébert \& Rochette, 2004:232). Volgens Ho, Matsubayashi, Wada, Kimura, Yano, Otsuka, Fujisawa, Kita en Saijoh (2003:79) sal daar met nuwe oë na veroudering gekyk moet word, naamlik dat lewe aan jare toegevoeg word in plaas daarvan dat jare aan die lewe toegevoeg word. Die meeste bejaardes, ongeag of hulle daartoe in staat is of nie, woon steeds in die gemeenskap (Auslander, Soffer \& Auslander, 2003:209).

Dienssentrums het dus hul ontstaan te danke aan die toename in die getal bejaardes, die behoefte aan meer formele dienste vir bejaardes soos deur dienssentrums georganiseer kan word en die koste van versorging van bejaardes in tehuise vir bejaardes. Dit word vandag steeds algemeen aanvaar dat bejaardes so lank moontlik selfstandig in die gemeenskap moet funksioneer met behulp van gemeenskapsdienste wat deur dienssentrums gebied behoort te word (Strydom \& Rip, 1989:201). Ten einde in hierdie doel te slaag, behoort dienssentrums 'n verskeidenheid gemeenskapsdienste aan bejaardes te bied. 
Gemeenskapsdienste vir bejaardes verwys in die wydste sin van die woord na alle dienste wat aan bejaardes gelewer word om hul vlak van funksionering te verhoog en hulle daartoe in staat te stel om langer selfstandig in die gemeenskap aan te bly. Meer konkreet impliseer gemeenskapsdienste vir bejaardes onder andere huishoudelike hulpdienste, gesondheidsdienste, maatskaplikewerkdienste en ontspannings- en vryetydsbestedingsdienste. Dit is dus duidelik dat groter getalle bejaardes in die toekoms sodanige dienste deur die meer formele sektor, soos dienssentrums vir bejaardes, sal benodig. Algemeen geldende riglyne kan vir die funksionering van dienssentrums voorgestel word, maar elke dienssentrum sal egter op die unieke behoeftes van die spesifieke gemeenskap ingestel moet wees (Strydom, 1994:27).

Dienssentrums sal toenemend innoverend te werk moet gaan om gemeenskapsdienste wat kostedoeltreffend en behoeftebevredigend is te ontwikkel (Strydom, 1995:24). Die dienssentrum het tans 1111 lede wat ledegeld betaal het (Potchefstroom Dienssentrum vir Bejaardes, 2005a:3). Volgens die Sentrale Statistiekdiens, soos deur die Potchefstroom Dienssentrum vir Bejaardes (2005b:12) aangehaal, het die bejaarde bevolking van Potchefstroom alreeds in 2001 uit 10397 persone bestaan. Daar kan dus afgelei word dat net ongeveer $11 \%$ van die bejaarde bevolking van Potchefstroom deur die dienssentrum bedien word.

Om 'n diens van gehalte in die gemeenskap te kan lewer, het die bestuur van die Potchefstroom Dienssentrum vir Bejaardes die behoefte ervaar om wetenskaplik vas te stel wat die houding teenoor en persepsies van die Potchefstroom Dienssentrum vir Bejaardes by sowel lede as nie-lede is, asook om bestaande dienste te evalueer. Op dié wyse kan daar steeds op die bestaande dienste verbeter word.

\section{TEORETIESE BEGRONDING}

Die sterkteperspektief is dié praktykbenadering wat 'n pleidooi lewer vir verandering in die siening van 'n patologie- na 'n sterkteperspektief wat op die beskikbare sterktes van mense fokus. Dit is nie 'n nuwe benadering nie, maar veel eerder ' $n$ herbesinning van die aanvanklike grondslae van maatskaplike werk (Gray \& Van Rooyen, 2002:193; Saleebey, 1996). Sterktes verwys na individuele en omgewingskenmerke van mense om aan te pas by en werk te maak van uitdagende omstandighede in hul leefwêreld (Ryke, 2004:6). In die sterkteperspektief val die klem dus op die kliënt se vermoë om te kan groei, te kan verander en te kan ontwikkel binne 'n milieu van aanmoediging en aanvaarding met die fokus op die huidige sterktes van die kliënt ten einde samehorigheidsgevoel te bereik (Geyer, 2003:102).

Verder word in hierdie studie van die ontwikkelingsperspektief uitgegaan, naamlik dat veroudering as 'n normale fase in die lewensloop van die mens beskou word waar take en rolle steeds bemeester moet word (Swanepoel, 1999:23). Die lewensfase van bejaardheid het, net soos die kleuter- en adolessensiestadium, ook sekere unieke uitdagings wat bemeester moet word. Hier word gedink aan aspekte soos verhuising na 'n kleiner wooneenheid, aftrede van die werksloopbaan en die beskikbaarheid van meer vrye tyd. Al hierdie veranderinge dwing die bejaarde daartoe om aanpassings met betrekking tot sy/haar lewenstyl te maak.

Heelwat aspekte speel 'n rol in die lewe van 'n bejaarde ten einde te bepaal in watter mate 'n persoon suksesvol sal verouder. Reker (2001:43-44) doen 'n evaluering van bestaande modelle van veroudering en kom tot die gevolgtrekking dat daar nie werklik 'n algemeen aanvaarde konseptualisering van suksesvolle veroudering bestaan nie. Daar bestaan egter eenstemmigheid dat 'n omvattende benadering ten opsigte van suksesvolle veroudering verskillende kriteria en aanpassingspatrone by veroudering behels. Reker (2001:44) waag tog om suksesvolle veroudering te omskryf ooreenkomstig optimale aanpassing by veranderende lewensomstandighede wat uit die aard van die saak 'n kultuurgebonde aangeleentheid is. 
Morrow-Howell (1992) verwys na fisiese gesondheid, psigiese gesondheid, maatskaplike ondersteuning, die fisiese omgewing, die vlak van funksionering, aanpassingstyl en die benutting van formele diensleweringstelsels as van die belangrikste faktore om te bepaal of ' $n$ persoon suksesvol by die eise van veroudering sal aanpas. Gemeenskapsdiente vir bejaardes behoort dus te alle tye binne die konteks van die ontwikkelingsgerigte diensleweringsraamwerk te geskied. Reker (2001:44) voeg gelukkigheid en lewenstevredenheid by voorgenoemde aspekte. Potts (1997) wys weer op die belangrikheid van maatskaplike ondersteuning en spesifiek die ondersteuning van vriende. Die ondersteuningsnetwerk vir bejaardes word deur Wenger (1984:136) wyer omskryf en verwys na almal met wie die bejaarde noue kontak het of van wie hy/sy hulp ontvang.

Bejaardes is juis een populasie wat by die sterkteperspektief kan baat, ongeag of dit die teorie of die praktyk is (Lewis, 1996:99). Die mate waarin 'n bejaarde suksesvol verouder, hang grootliks af van 'n positiewe ingesteldheid teenoor die lewe en die vermoë om by veranderinge aan te pas. Aanpassing by lewensveranderinge gebeur nie oornag en vanself nie, maar vereis doelgerigte inspanning van elke ouer persoon. Om dus suksesvol by die lewensfase van bejaardheid in te skakel, vereis van die individu om steeds binne die raamwerk van beskikbare kragte te ontwikkel.

\section{DOELSTELLING EN DOELWITTE}

Die doelstelling met hierdie ondersoek was om die bestaande gemeenskapsdienste, soos deur die Potchefstroom Dienssentrum vir Bejaardes aangebied, te evalueer.

Die volgende doelwitte vir die ondersoek kan uit die oorhoofse doelstelling afgelei word:

- Om die huidige profiel van bejaardes in die Potchefstroom-gemeenskap vas te stel.

- Om die redes vir deelname of nie-deelname aan die aktiwiteite van die dienssentrum vas te stel.

- Om vas te stel van watter spesifieke dienste bejaardes gebruik maak of sou wou gebruik maak.

- Om aanbevelings te maak met betrekking tot die motivering van bejaardes om bestaande dienste beter te benut.

\section{NAVORSINGSMETODOLOGIE}

Die ondersoek bevat elemente van beide kwantitatiewe en kwalitatiewe navorsing en alle pogings is aangewend om die bevindinge komplimenterend tot mekaar te benut (Neuman, 2003:139). Die opnameprosedure (Monette, Sullivan \& DeJong, 2005:158), en spesifiek persoonlike onderhoude (Babbie, 2004:263-268), is vir die studie benut. Daar is besluit om van 'n niewaarskynlikheidsteekproef (De Vos, Strydom, Fouché, \& Delport., 2005:201-203) gebruik te maak omdat die navorser juis op 'n persoonlike vlak met bejaardes wat deur iemand na aan hulle geselekteer is, wou werk. Gevolglik is die doelgerigte steekproef (Neuman, 2003:213-214) benut.

Vierdejaarstudente in Maatskaplike Werk het die ondersoek as 'n opdrag van die navorsingsmodule gedoen (Strydom, 2005). 'n Naamlys van alle kerkgroepe in Potchefstroom is van die dienssentrum verkry, en studente is by bepaalde gemeentes ingedeel en van ' $n$ telefoonnommer van die betrokke dominee voorsien. Daar is van die studente verwag om self kontak met die dominee te maak en 'n aantal name van bejaardes te bekom. Aangesien Die Potchefstroomse Dienssentrum vir Bejaardes sekere uitsonderings maak vir 55-jariges vir aansluiting as lede en omdat die ondersoek onder andere ook op die toekomstige benutting van gemeenskapsdienste gerig is, is besluit om enige en bo die ouderdom van 55 jaar by die ondersoek te betrek. Afgesien van enkele dominees en bejaardes wat nie aan die ondersoek wou meewerk nie 
en enkele studente wat nie die verlangde skedules kon invul nie, is geen ander probleme ondervind nie. Daar is volstaan met 142 bruikbare skedules wat 'n goeie aanduiding van die stand van sake gegee het. Aangesien daar van 'n relatief klein steekproef gebruik gemaak is, is die data per hand verwerk en soms geklassifiseer en soms in tabelle aangebied.

\section{BEVINDINGE}

\section{Identifiserende besonderhede}

\section{- Geslag}

Van die 142 deelnemers was 54 (38\%) manlik, teenoor 88 (62\%) vroulik. Gesien teen die syfers soos deur die Sentrale Statistiekdiens aangebied en deur die Potchefstroom Dienssentrum vir Bejaardes (2005b:9-10) aangehaal, is $41 \%$ van die bejaarde inwoners van Potchefstroom mans en $59 \%$ van hulle vroue. Die 38\%-mans en 62\%-vroue wat aan die ondersoek deelgeneem het, korreleer dus goed met syfers soos vir Potchefstroom aangebied.

\section{- Ouderdom}

Die ouderdomsverspreiding van die deelnemers word deur Tabel 1 aangedui.

TABEL 1

OUDERDOM

\begin{tabular}{|l|c|c|}
\hline Ouderdom & Aantal & Persentasie \\
\hline 55-59 jaar & 34 & $23,94 \%$ \\
\hline 60-64 jaar & 21 & $14,79 \%$ \\
\hline 65-69 jaar & 23 & $16,20 \%$ \\
\hline $70-74$ jaar & 26 & $18,31 \%$ \\
\hline $75-79$ jaar & 25 & $17,61 \%$ \\
\hline $80-84$ jaar & 11 & $7,75 \%$ \\
\hline $85-89$ jaar & 1 & $0,70 \%$ \\
\hline $90+$ & 1 & $0,70 \%$ \\
\hline Totaal & 142 & $100,00 \%$ \\
\hline
\end{tabular}

Daar kan dus afgelei word dat die enkele grootste ouderdomsgroep tussen 55 en 59 jaar val. Daar is ook groot groepe tussen 60 en 79 jaar, met 'n afplatting ná 80 en veral ná 85 jaar. Dit is begryplik dat min bejaardes bo 80 jaar selfstandig woon. 


\section{- Huwelikstatus}

Die huwelikstatus van deelnemers word in Tabel 2 weerspieël.

TABEL 2

HUWELIKSTATUS

\begin{tabular}{|l|c|c|}
\hline Huwelikstatus & Aantal & Persentasie \\
\hline Getroud & 84 & $59,15 \%$ \\
\hline Weduwee/wewenaar & 45 & $31,69 \%$ \\
\hline Geskei & 7 & $4,93 \%$ \\
\hline Nooit getroud nie & 6 & $4,23 \%$ \\
\hline Totaal & 142 & $100,00 \%$ \\
\hline
\end{tabular}

Daar kan duidelik afgelei word dat die meeste bejaardes tans nog getroud is, teenoor ' $n$ relatief groot persentasie weduwees en wewenaars. Daar was ook enkele deelnemers wat geskei was of nooit getroud nie.

\section{- Woonplek}

Die huidige woonplek van deelnemers word in Tabel 3 weergegee.

TABEL 3 WOONPLEK

\begin{tabular}{|l|c|c|}
\hline Woonplek & Aantal & Persentasie \\
\hline By kinders in woonstel & 5 & $3,52 \%$ \\
\hline By kinders in die huis & 14 & $9,86 \%$ \\
\hline Woonstel & 19 & $13,38 \%$ \\
\hline Eie huis & 97 & $68,31 \%$ \\
\hline Huurhuis & 7 & $4,93 \%$ \\
\hline Totaal & 142 & $100,00 \%$ \\
\hline
\end{tabular}

Gesien teen die agtergrond van die ouderdom van die deelnemers en dat dit meestal selfstandige bejaardes is wat in die gemeenskap woonagtig is, is dit nie vreemd dat die oorgrote meerderheid in hul eie huise woonagtig is nie. Daar was ook 'n redelike antal wat in eie woonstelle of by die kinders woonagtig is, teenoor enkele deelnemers wat in huurhuise of by kinders in woonstelle woonagtig is. Auslander et al. (2003:217) het bevind dat bejaardes wat alleen woon, meer geneig is om aan gemeenskapsaktiwiteite deel te neem as bejaardes wat tussen ander bejaardes woonagtig is. 


\section{Omskrywing van 'n dienssentrum}

Die volgende response kan beskou word as verteenwoordigend van die standpunte van deelnemers rakende die versoek om 'n dienssentrum te omskryf.

- Plek waar bejaardes dienste ontvang (37).

- Hulpverlening aan bejaardes (21).

- Plek waar bejaardes bymekaar kom (12).

- Ek weet nie wat'n dienssentrum is nie (11).

- Om die lewe daar saam te geniet (4).

- Die dienssentrum hou bejaardes besig (3).

- Plek waar ryk bejaardes sosiale byeenkomste hou (3).

- Die dienssentrum gee om vir bejaardes (2).

Uit die response kan duidelik afgelei word dat daar heelwat onduidelikheid en vaagheid oor die begrip dienssentrum bestaan. Uit 'n studie van Strydom (2003:70) kan ook gesien word dat die deelnemers aan daardie ondersoek selfs nie 'n tehuis vir bejaardes/versorgingsoord kon omskryf nie. Ten spyte van alle pogings wat aangewend word om dienste aan bejaardes aan die gemeenskap bekend te stel, blyk daar steeds onkunde te bestaan en behoort bekendstellingsveldtogte steeds geloods te word.

\section{Dienste tans deur lede benut}

Aangesien slegs 43 (30\%) van die deelnemers tans lede van die dienssentrum is, sal die vrae oor dienste aan lede dus net op hierdie 43 deelnemers fokus.

\section{- Dienste waarvan tans gebruik gemaak word}

TABEL 4

DIENSTE TANS DEUR LEDE BENUT

\begin{tabular}{|c|c|c|c|}
\hline Bepaalde diens & $\mathbf{J a}$ & Nee & Totaal \\
\hline Etes by dienssentrum & $25(58,14 \%)$ & $18(41,86 \%)$ & $43(100,00 \%)$ \\
\hline Aanry-etes & $9(20,93 \%)$ & $34(79,07 \%)$ & $43(100.00 \%)$ \\
\hline Vervoerdienste & $8(18,61 \%)$ & $35(81,39 \%)$ & $43(100,00 \%)$ \\
\hline Maatskaplikewerk-dienste & $19(44,19 \%)$ & $24(55,81 \%)$ & $43(100,00 \%)$ \\
\hline Gesondheidsdienste: & ---- & ---- & --- \\
\hline Kliniekdienste & $19(44,19 \%)$ & $24(55,81 \%)$ & $43(100,00 \%)$ \\
\hline Voetsorg & $22(51,16 \%)$ & $21(48,84 \%)$ & $43(100,00 \%)$ \\
\hline Tuisverplegingsdienste & $7(16,28 \%)$ & $36(83,72 \%)$ & $43(100,00 \%)$ \\
\hline Tuisversorgingsdienste & $1(2,33 \%)$ & $42(97,67 \%)$ & $43(100,00 \%)$ \\
\hline Verhuring van hulpmiddels & $1(2,33 \%)$ & $42(97,67 \%)$ & $43(100,00 \%)$ \\
\hline Haarsalon & $14(32,56 \%)$ & $29(67,44 \%)$ & $43(100,00 \%)$ \\
\hline Tuishulp & $15(34,88 \%)$ & $28(65,12 \%)$ & $43(100,00 \%)$ \\
\hline Tuinhulp & $10(23,26 \%)$ & $33(76,74 \%)$ & $43(100,00 \%)$ \\
\hline Uitstappies en toere & $16(37,21 \%)$ & $27(62,79 \%)$ & $43(100,00 \%)$ \\
\hline
\end{tabular}


Uit Tabel 4 blyk dit duidelik dat die dienste waarvan die meeste gebruik gemaak word, die etes by die dienssentrum, voetsorg, maatskaplikewerk-dienste en kliniekdienste is. Van sekere gesondheidsdienste, soos tuisversorgingsdienste en verhuring van hulpmiddels, word tans nie veel gebruik gemaak nie, miskien juis omdat lede dit tans nie nodig het nie.

\section{- Dienste wat as die waardevolste deur lede beskou word}

Op 'n kwalitatiewe vraag oor die dienste wat lede as die waardevolste beskou, is die volgende response verkry:

- Uitstappies en toere (17).

- Sosiale byeenkomste (12).

- Tuisverpleging (10).

- Kliniekdienste (6).

- Voetsorg (6).

- Aanry-etes (6).

Dit is dus duidelik dat die dienste waarvan lede tans gebruik maak, nie noodwendig die dienste is wat hulle as die waardevolste vir bejaardes beskou nie.

\section{Dienste in oorweging deur nie-lede}

Die oorgrote meerderheid deelnemers aan die ondersoek, naamlik $99(70 \%)$, is tans nie lede van die dienssentrum nie en sal die vrae oor dienste aan nie-lede dus net deur hierdie 99 deelnemers beantwoord word.

\section{- Dienste waarvan nie-lede gebruik sal maak}

TABEL 5

DIENSTE WAT NIE-LEDE SAL BENUT

\begin{tabular}{|l|c|l|c|}
\hline Bepaalde diens & \multicolumn{1}{|c|}{ Ja } & Nee & \multicolumn{1}{c|}{ Totaal } \\
\hline Etes by dienssentrum & $37(37,37 \%)$ & $62(62,63 \%)$ & $99(100,00 \%)$ \\
\hline Aanry-etes & $27(27,27 \%)$ & $72(72,73 \%)$ & $99(100,00 \%)$ \\
\hline Vervoerdienste & $29(29,29 \%)$ & $70(70,71 \%)$ & $99(100,00 \%)$ \\
\hline Maatskaplikewerk-dienste & $33(33,33 \%)$ & $66(66,67 \%)$ & $99(100,00 \%)$ \\
\hline Gesondheidsdienste: & ---- & ---- & ----- \\
\hline Kliniekdienste & $51(51,52 \%)$ & $48(48,48 \%)$ & $99(100,00 \%)$ \\
\hline Voetsorg & $35(35,35 \%)$ & $64(64,65 \%)$ & $99(100,00 \%)$ \\
\hline Tuisverplegingsdienste & $23(23,23 \%)$ & $76(76,77 \%)$ & $99(100,00 \%)$ \\
\hline Tuisversorgingsdienste & $7(7.07 \%)$ & $92(92,93 \%)$ & $99(100,00 \%)$ \\
\hline Verhuring van hulpmiddels & $15(15,15 \%)$ & $84(84,85 \%)$ & $99(100,00 \%)$ \\
\hline Haarsalon & $42(42,42 \%)$ & $57(57,58 \%)$ & $99(100,00 \%)$ \\
\hline Tuishulp & $22(22,22 \%)$ & $77(77,78 \%)$ & $99(100,00 \%)$ \\
\hline Tuinhulp & $27(27,27 \%)$ & $72(72,73 \%)$ & $99(100,00 \%)$ \\
\hline Uitstappies en toere & $44(44,44 \%)$ & $55(55,56 \%)$ & $99(100,00 \%)$ \\
\hline
\end{tabular}


Uit Tabel 5 is dit duidelik dat kliniekdienste, uitstappies en toere, haarsalon, etes by dienssentrum, voetsorg en maatskaplikewerk-dienste as die gewildste dienste deur nie-lede van die dienssentrum aangedui word. Aan die ander kant beskou nie-lede tuisversorgingsdienste, verhuring van hulpmiddels, tuishulp, tuinhulp en aanry-etes as die ongewildste dienste. Die feit dat 44 van die bejaardes uitstappies as 'n waardevolle diens beskou, onderskryf Benokraitis (1996:527) se siening dat bejaardes uitstappies as 'n belangrike faktor beskou om eensaamheid te verdryf. Die gewildheid van haarsalondienste kan toegeskryf word daaraan dat vroue hierdie diens benut en dat die meeste lede van dienssentrums tog ook vroue is (Auslander et al., 2003:210). Die belangrikheid van kliniek- en voetsorgdienste word reg deur die verslag as waardevol aangedui.

Die aanduiding van maatskaplikewerk-dienste as 'n hoë prioriteit kan moontlik daaraan toegeskryf word dat bejaardes toenemend verliese op alle vlakke van maatskaplike funksionering ervaar en die waarde besef van hulpverleningstrukture en gesonde interpersoonlike verhoudings, soos met die huweliksmaat, kinders, kleinkinders en vriende ten einde hulle met lewensoorgange en aanpassings by veranderende omstandighede te help (Garden, 1991:93-103; Keigher, Fortune \& Witkin, 2000:108-109; Phillips, 1984:12-32; Stephens, 1994:23-24).

\section{- Dienste wat nie-lede as die waardevolste beskou}

Op 'n kwalitatiewe vraag oor die dienste wat nie-lede as die waardevolste beskou, is die volgende bevind:

- $\quad$ Kliniekdienste (27).

- $\quad$ Etes by dienssentrum (18).

- Tuisverpleging (17).

- Maatskaplikewerk-dienste (17).

- Sosiale byeenkomste (17).

- Aanry-etes (14).

Weer eens, soos in die geval van lede, blyk dit dat die dienste waarvan nie-lede gebruik sou maak, nie noodwendig die dienste is wat bejaardes as die waardevolste beskou nie. Die benutting van dienste verskil ook tussen die groepe. By die dienste waarvan dienssentrumlede tans gebruik maak, is die fokus meer op etes, voetsorg, maatskaplikewerk-dienste en kliniekdienste, maar by die dienste wat hulle as die waardevolste beskou, val die klem op vryetydbestedingsdienste. Die enigste ooreenkomste tussen die twee kategorieë lede kan deurgetrek word na kliniekdienste en voetsorg.

In die geval van nie-diensentrumlede kom 'n groter mate van ooreenkoms voor tussen dienste waarvan nie-lede gebruik sal maak en dienste wat as die waardevolste beskou word, byvoorbeeld kliniekdienste, etes by dienssentrum, maatskaplikewerk-dienste en vryetydbestedingsdienste. Daar is bewyse dat sekere dienste, soos etes en kliniekdienste, wêreldwyd aan die toeneem is (Benokraitis, 1996:529). Geneeskundige dienste aan bejaardes het duur geword, en veral diegene wat nie oor mediese fondse beskik nie, sal toenemend van die dienste van dienssentrums gebruik moet maak (Belsky, 1999:141). Gemeenskapsdienste vir bejaardes word juis ontwikkel om aan die behoeftes van hierdie spesiale groep in die samelewing te voldoen ten einde die lewensgehalte en sekuriteit van bejaardes in die gemeenskap te verhoog (Auslander et al., 2003:209).

\section{Redes vir nie-aansluiting by die dienssentrum}

Eerstens is 'n oop vraag aan deelnemers gestel oor die redes vir nie-aansluiting by die dienssentrum en daarna 'n geslote vraag waarin moontlike redes vir nie-aansluiting gelys is. Op die oop vraag is die volgende kwalitatiewe redes vir nie-aansluiting aangevoer: 
- $\quad$ Ek is te besig met sake soos werk en die huishouding (32).

- $\quad$ Ek kan nog na myself omsien (13).

- Dit is te duur; ek kan dit nie bekostig nie (11).

- Is nog te jonk vir so baie ou mense (10).

- Weet nie waar die dienssentrum is nie (7).

- $\quad$ My kinders sien om na my (4).

- $\quad$ Ek het geen behoefte daaraan nie (3).

- Pas nie daar tussen die rykes in nie (3).

Onomwonde kan verklaar word dat verreweg die meeste bejaardes gemeld het dat hulle te besig is om by die dienssentrum betrokke te raak; dat hulle nog na hulleself kan omsien; dat die dienste te duur is; en dat hulle hulle nog te jonk ag om by die dienssentrum aan te sluit. Onkunde oor 'n dienssentrum en die lede van dienssentrums spreek duidelik uit enkele opmerkings.

Ten opsigte van die geslote vraag oor die redes wat ' $n$ rol speel in die besluit van die deelnemers aan die ondersoek om nie by die dienssentrum aan te sluit nie, is die volgende waargeneem.

TABEL 6

REDES VIR NIE-AANSLUITING BY DIE DIENSSENTRUM

\begin{tabular}{|l|l|l|l|l|}
\hline Rede & \multicolumn{1}{|c|}{ Ja } & Onseker & \multicolumn{1}{c|}{ Nee } & Totaal \\
\hline Te veel bejaardes & $25(25,25 \%)$ & $23(23,23 \%)$ & $51(51,52 \%)$ & $99(100,00 \%)$ \\
\hline Meng met jonger persone & $40(40,40 \%)$ & $14(14,14 \%)$ & $45(45,46 \%)$ & $99(100,00 \%)$ \\
\hline Is net vir ryk mense & $21(21,21 \%)$ & $23(23,23 \%)$ & $55(55,56 \%)$ & $99(100,00 \%)$ \\
\hline Te besig om te gaan & $62(62,63 \%)$ & $9(9,09 \%)$ & $28(28,28 \%)$ & $99(100,00 \%)$ \\
\hline Verkies eie geselskap & $39(39,39 \%)$ & $13(13,13 \%)$ & $47(47,48 \%)$ & $99(100,00 \%)$ \\
\hline Verkies een/twee vriende & $47(47,48 \%)$ & $20(20,20 \%)$ & $32(32,32 \%)$ & $99(100,00 \%)$ \\
\hline Te veel pratery & $19(19,19 \%)$ & $31(31,31 \%)$ & $49(49,50 \%)$ & $99(100,00 \%)$ \\
\hline Dienste is oorgeorganiseerd & $12(12,12 \%)$ & $42(42,42 \%)$ & $45(45,46 \%)$ & $99(100,00 \%)$ \\
\hline Voel nog te jonk & $58(58,59 \%)$ & $10(! 0,10 \%)$ & $31(31,31 \%)$ & $99(100,00 \%)$ \\
\hline Dienste is te duur & $19(19,19 \%)$ & $33(33,33 \%)$ & $47(47,48 \%)$ & $99(100,00 \%)$ \\
\hline Geen aktiwiteite vir my nie & $10(10,10 \%)$ & $42(42,42 \%)$ & $47(47,48 \%)$ & $99(100,00 \%)$ \\
\hline
\end{tabular}

Die belangrikste redes vir nie-aansluiting by die dienssentrum korreleer goed met die redes soos in die kwalitatiewe vraag bevind, naamlik dat hulle te besig is om die dienssentrum se byeenkomste by te woon; dat hulle nog te jonk voel; dat hulle een of twee vriende bo die groot groep verkies; 
dat hulle eerder met jonger mense omgaan en hul eie geselskap verkies. Die meeste van hierdie redes kan teruggevoer word na ontkenning van veroudering en dat hulle nie op hul gemak voel tussen 'n groot groep mense nie. Die oorgrote meerderheid redes wat aangevoer is, kan hanteer word deur bekendstellingsveldtogte te loods om veral die onkunde by die jonger groep bejaardes teen te werk.

\section{Algemene opmerkings}

'n Aantal algemene opmerkings is ook deur deelnemers gemaak en kan soos volg aangedui word:

- $\quad$ Dienssentrums doen wonderlike werk en moet aangemoedig word (13).

- $\quad$ 'n Tak moet op die Bult geopen word - die huidige dienssentrum is te ver (10).

- Meer inligting word verlang oor die take van 'n dienssentrum. Dienste moet beter bemark word (10).

- $\quad$ Tuisverpleging moet verder uitgebrei word (6).

- Daar is min bystand vir bejaardes met min geld (5).

- Kinders behoort meer by hulle ouers betrokke te raak (5).

- Meer besoekers en sprekers van buite word by klubbyeenkomste verlang (4).

Van die belangrikste opmerkings wat deur deelnemers gemaak is, is ' $n$ satelietdienssentrum/klub in ander dele van die gemeenskap, beter bekendstelling van die dienssentrum, die koste-aspek en die betrokkenheid van kinders by hul bejaarde ouers se lewens.

\section{Waarnemings deur veldwerkers}

Die volgende kan as verteenwoordigend beskou word van die verskeidenheid waarnemings wat deur die veldwerkers self gemaak is:

- Bejaardes is nog baie aktief (16).

- Veldwerkers is vriendelik ontvang (12).

- 'n Gebrek aan kennis oor 'n dienssentrum kom voor (9).

- Van die deelnemers is iesegrimmig en negatief teenoor alles in die lewe (8).

- Bejaardes wek die indruk van vrolikheid en lewensblyheid (6).

- Daar is vyandigheid teenoor die dienssentrum omdat Christelikheid volgens hulle nie by die dienssentrum eerbiedig word nie (4).

- Van die deelnemers sal nooit weer die dienssentrum besoek nie omdat hulle 'n baie slegte ervaring met 'n personeellid en bejaardes gehad het (4).

Hierdie opmerkings bevestig dat die deelnemers aan die ondersoek jong bejaardes is; dat daar 'n gebrek aan kennis oor 'n dienssentrum onder baie mense voorkom; dat sommige bejaardes dankbaar is oor die geleenthede wat hulle gebied word; en dat ander ' $n$ grief teen die lewe in die geheel koester. 'n Paar deelnemers het ook beweer dat Christelikheid by die dienssentrum verwaarloos word en dat hulle êrens 'n slegte ervaring met 'n personeellid of ander bejaardes gehad het. Laasgenoemde is normale verskynsels wat voorkom waar dienste aan groot groepe mense gelewer word. Dikwels word dit ook as verskoning aangevoer om nie hand in eie boesem te steek nie.

\section{BEVINDINGS}

- Die enkele grootste groep bejaardes $(24 \%)$ wat in die ondersoek betrek is, is die groep tussen die ouderdomme 55 en 59 jaar, van wie $38 \%$ mans is.

- Ongeveer $60 \%$ van die deelnemers is tans nog getroud.

- Die meeste van hierdie bejaardes $(68 \%)$ woon tans nog in hulle eie wonings. 
- Ten spyte van die bekendheid van die Potchefstroom Dienssentrum vir Bejaardes is heelwat bejaardes steeds oningelig oor ' $n$ dienssentrum en die dienste wat gelewer word en is hulle baie vaag in hul omskrywing van die begrip.

- Slegs 30\% van die deelnemers aan die ondersoek is tans lede van die dienssentrum.

- Dit is opgemerk dat daar verskille onder lede en nie-lede bestaan tussen die dienste wat benut word/benut sal word en die dienste wat as die waardevolste beskou word.

- By die dienste waarvan dienssentrumlede tans gebruik maak, is die fokus meer op etes, voetsorg, maatskaplikewerk-dienste en kliniekdienste, maar by die dienste wat hulle as die waardevolste vir bejaardes beskou, val die klem oorwegend op vryetydbestedingsdienste. Die ooreenkomste tussen die twee kategorieë kom neer op kliniekdienste en voetsorg.

- In die geval van die nie-dienssentrumlede is die ooreenkoms tussen die dienste waarvan hulle gebruik sou mak en die dienste wat as die waardevolste vir bejaardes beskou word, groter. Hier kan kliniekdienste, etes, maatskaplikewerk-dienste en vryetydbestedingsdienste as voorbeelde genoem word.

- Die dienste waarvan bejaardes, dus die lede en nie-lede, gebruik maak/sal maak en wat bejaardes as 'n hoë prioriteit beskou, is etes, kliniekdienste, maatskaplikewerk-dienste en vryetydbestedingsdienste.

- Omdat die bejaardes meestal nog gesond en selfversorgend is, sal hulle tans nie van tuisversorgings- en tuisverplegingsdienste gebruik maak nie. Dit maak nog nie deel uit van hul verwysingsraamwerk dat hulle moontlik in die toekoms van hierdie dienste gebruik sal moet maak nie.

- Die redes vir nie-aansluiting by die dienssentrum korreleer goed tussen die kategorieë wat in die kwalitatiewe en kwantitatiewe vrae bevind is. Die vernaamste redes wat vir nie-aansluiting aangevoer is, is dat hulle te besig is om die dienssentrum se byeenkomste by te woon; dat hulle nog te jonk voel; dat hulle een/twee vriende bo die groot groep van die dienssentrum verkies; dat hulle eerder met jong mense omgaan en hul eie geselskap verkies. Genoemde redes kan hoofsaaklik in twee kategorieë geklassifiseer word, naamlik ontkenning van veroudering en bedreiging deur die groot groep. Hier kan bekendstellingsveldtogte 'n groot rol speel om onkunde uit die weg te ruim. Redes soos dat dienste te duur is; dat dienssentrums net vir ryk mense beskikbaar is; en dat die beskikbare dienste nie alle belangstellingsvelde dek nie, behoort egter aandag te geniet.

- By algemene opmerkings is die volgende genoem, naamlik die moontlikheid van 'n satellietdienssentrum/klub in ander dele van die gemeenskap, beter bekendstelling van die dienssentrum, die koste-aspek en die betrokkenheid van kinders by hul bejaarde ouers se lewens.

- Die volgende kan as enkele waarnemings van veldwerkers beskou word, naamlik dat die meeste deelnemers aan die projek jong bejaardes is; dat daar 'n gebrek aan kennis oor die werking van 'n dienssentrum bestaan; dat sommige bejaardes dankbaar is en ander 'n grief teen die lewe in die geheel koester.

\section{AANBEVELINGS}

- 'n Aggressiewe bemarkingsveldtog moet geloods word om die dienssentrum, met al die verskillende gemeenskapsdienste en die aard daarvan, aan beide ouer bejaardes en jonger bejaardes bekend te stel. Die jonger bejaardes kan op hierdie wyse ook besef dat die dienssentrum 'n bydrae tot hul lewens kan maak en dat hulle nie huiwerig hoef te wees om aan te sluit nie. 
- Die Beheerraad van die Potchefstroomse Dienssentrum vir Bejaardes sal deeglik daarmee rekening moet hou dat die ondersoek 'n groot groep jonger bejaardes en heelwat mans ingesluit het, wat beslis vernuwing in denke sal verg aangesien die tradisionele teikengroep van dienssentrums hoofsaaklik ouer bejaardes en dames was.

- Die redes vir nie-aansluiting by die dienssentrum kan hoofsaaklik aan onkunde, ontkenning van veroudering en die bedreiging wat die groot groep inhou, toegeskryf word. Al hierdie besware kan vanaf die dienssentrum se kant, met spesifieke aandag van die maatskaplike werker, met behulp van sensitiewe bekendstellingsveldtogte in kleingroepverband uit die weg geruim word. Hierdie pogings kan ook die koste van dienste en die verskillende belangstellingsvelde onder die loep neem.

- Die stigting van 'n satelietdienssentrum of klub in ander dele van die gemeenskap kan sterk aangemoedig word. Hier word veral gedink aan die noordelike deel van die gemeenskap wat ver van die bestaande dienssentrum geleë is. Op dié wyse kan groepe bejaardes wat op ekonomiese, godsdienstige en sosiale vlak met mekaar sosialiseer, betrek word.

\section{SAMEVATTING}

Hierdie ondersoek het gehandel oor 'n behoeftebepaling by bejaardes in die groter Potchefstroomarea met die doel om die onderskeie bestaande gemeenskapsdienste vir bejaardes, soos deur die Potchefstroom Dienssentrum vir Bejaardes aangebied, te evalueer. Hierdie studie het vasgestel waarom sommige bejaardes nie lede van die dienssentrum is nie; wat die tipe diens is waarvan bestaande dienssentrumlede en nie-lede gebruik sou maak; en wat hulle as waardevolle dienste vir bejaardes beskou. Enkele aanbevelings is ook gemaak ten opsigte van moontlike stappe wat deur die dienssentrum gedoen kan word om die bestaande dienste steeds te verbeter.

\section{BIBLIOGRAFIE}

AUSLANDER, G.K., SOFFER, M. \& AUSLANDER, B.A. 2003. The supportive community: Help seeking and service use among elderly people in Jerusalem. Social Work Research, 27(4):209-221.

BABBIE, E. 2004. The practice of social research. London: Thomson Wadsworth Publishers.

BELSKY, J.K. 1999. The psychology of aging: Theory, research, and interventions. Johannesburg: Brooks/Cole Publishing Company.

BENOKRAITIS, N.V. 1996. Marriages and families: Changes, choices and constraints. New Jersey: Prentice Hall.

DE VOS, A.S., STRYDOM, H., FOUCHé, C.B. \& DELPORT, C.S.L. 2005. Research at grass roots: For the social sciences and human service professions. Pretoria: Van Schaik Publishers.

ECKLEY, S.C.A. 1996. Toekomstige Suid-Afrika: Uitdagings en opsies. Kaapstad.

GARDEN, A. 1991. Elemental human experiences of the aged. Pretoria: Universiteit van SuidAfrika. (M.A.-Verhandeling.)

GEYER, 1.S. 2003. Maatskaplike groepwerk aan alkoholafhanklike bejaardes ooreenkomstig die sterkteperspektief. Potchefstroom: Noordwes-Universiteit. (M.A.-Verhandeling.)

GRAY, M. \& VAN ROOYEN, C.A.J. 2002. The strengths perspective in social work: Lessons from practice. Social Work/Maatskaplike Werk, 38(3):193-201, Aug. 
HO, H.K., MATSUBAYASHI, K., WADA, T., KIMURA, M., YANO, S., OTSUKA, K., FUJISAWA, M., KITA, T. \& SAIJOH, K. 2003. What determines the life satisfaction of the elderly? Comparative study of residential care home and community in Japan. Geriatrics and Gerontology International, 3(2):79-85.

KEIGHER, S.M., FORTUNE, A.E. \& WITKIN, S.L. 2000. Aging and social work: The changing landscapes. Washington: NASW Press.

LEWIS, J.S. 1996. Sense of coherence and the strengths perspective with older persons. Journal of Gerontological Social Work, 26(3/4):99-112.

MINISTRY FOR WELFARE AND POPULATION DEVELOPMENT. 1997. White Paper for Social Welfare. Government Gazette 18166, Part 1-4 of Notice number 1108, 8 Aug. Pretoria: Government Printer.

MONETTE, D.R., SUlliVAN, T.J. \& DEJONG, C.R. 2005. Applied social research: A tool for the human services. London: Thomson Brooks/Cole Publishers.

MORROW-HOWELL, N. 1992. Mutidimentional assessment of the elderly client. Families in Society: The Journal of Contemporary Human Services, 73(7):395-407.

NEUMAN, W.L. 2003. Social research methods: Qualitative and quantitative approaches. London: Allyn \& Bacon.

PHILLIPS, P.A. 1984. The effects of service centre attendance on the psycho-social well-being of the aged. Johannesburg: Rand Afrikaans Universiteit. (MA-Verhandeling)

POTCHEFSTROOM DIENSSENTRUM VIR BEJAARDES. 2005a. Jaarverslag, 1 April 2004 tot 31 Maart 2005. Potchefstroom.

POTCHEFSTROOM DIENSSENTRUM VIR BEJAARDES. 2005b. Besigheidsplan, 2004-2005. Potchefstroom.

POTTS, M.K. 1997. Social support and depression among older adults living alone: The importance of friends within and outside of a retirement community. Social Work, 42(3):348-362, July.

REKER, G.T. 2001. Prospective predictors of successful aging in community-residing and institutionalized Canadian elderly. Ageing International, 27(1):42-64.

RYKE, E.H. 2004. The social niche of farm dwellers: A social work strengths approach. Potchefstroom: Noordwes-Universiteit. (Ph.D.-Proefskrif.)

SALEEBEY, D. 1996. The strengths perspective in social work practice: Extensions and cautions. Social Work, 41(3):296-305, May.

STEPHENS, B. 1994. An exploratory survey of the needs and adjustment to retirement of persons residing in Port Alfred. Grahamstown: Rhodes University. (M.A.-Verhandeling.)

STRYDOM, H. \& RIP, S. 1989. Persepsies en verwagtinge van inwoners in aftree-oorde. Maatskaplike Werk/Social Work, 25(3):201-207.

STRYDOM, H. 1994. Profiel van 'n swart bejaarde in "n stedelike gebied". Psigo-sosiale Navorsing en Praktyk/Psychosocial Research and Practice, 7(1):24-28. 
STRYDOM, H. 1995. Profiel van 'n swart bejaarde in "'n stedelike gebied" (Deel 2). Die Maatskaplikewerk-Navorser-Praktisyn/The Social Work Practitioner-Researcher, 8(1):1929, Sept.

STRYDOM, H. 2001. Social development and services for disadvantaged older persons in Potchefstroom. Die Maatskaplikewerk-Navorser-Praktisyn/The Social Work PractitionerResearcher, 13(2):98-117.

STRYDOM, H. 2003. The perceptions and needs of farm dwellers regarding aging, advanced age, and future perspectives. Journal of Gerontological Social Work, 42(1):59-76.

STRYDOM, H. 2005. Praktyknavorsing in Maatskaplike Werk (MWKG431). Potchefstroom: Noordwes Universiteit. (Studiegids)

SWANEPOEL, C.M. 1999. Maatskaplike behoeftes van bejaardes in Gauteng sedert 1994. Bloemfontein: Universiteit van die Oranje-Vrystaat. (PhD-Proefskrif)

TOURIGNY, A., DURAND, P.J., BONIN, L., HéBERT, R. \& ROCHETTE, L. 2004. Quasiexperimental study of the effectiveness of an integrated service delivery network for the frail elderly. Canadian Journal on Aging, 23(3):231-246.

WENGER, G.C. 1984. The supportive network: Coping with old age. London: George Allen \& Unwin.

WICCLAIR, M.R. 1993. Ethics and the elderly. New York: Oxford University Press.

Professor Herman Strydom en Dr Adriana Roux, senior lektor, Skool vir Psigo-Sosiale Gedragswetenskappe: Afdeling Maatskaplike Werk, Potchefstroomkampus van die Noordwes-Universiteit, Potchefstroom, Suid-Afrika. 